Columbia Law School

Scholarship Archive

1995

\title{
The Profession of Law: Columbia Law School's Use of Experiential Learning Techniques to Teach Professional Responsibility
}

Carol B. Liebman

Columbia Law School, cliebman@law.columbia.edu

Follow this and additional works at: https://scholarship.law.columbia.edu/faculty_scholarship

Part of the Legal Education Commons, Legal Ethics and Professional Responsibility Commons, and the Legal Profession Commons

\section{Recommended Citation}

Carol B. Liebman, The Profession of Law: Columbia Law School's Use of Experiential Learning Techniques to Teach Professional Responsibility, 58(3-4) LAW AND ConTEMP. PROBS. 73 (1995).

Available at: https://scholarship.law.columbia.edu/faculty_scholarship/958

This Article is brought to you for free and open access by the Faculty Publications at Scholarship Archive. It has been accepted for inclusion in Faculty Scholarship by an authorized administrator of Scholarship Archive. For more information, please contact scholarshiparchive@law.columbia.edu. 


\title{
THE PROFESSION OF LAW: COLUMBIA LAW SCHOOL'S USE OF EXPERIENTIAL LEARNING TECHNIQUES TO TEACH PROFESSIONAL RESPONSIBILITY
}

\author{
CAROL BENSINGER LIEBMAN*
}

\begin{abstract}
Tito was experiencing that inexorable law of human souls that we prepare ourselves for sudden deeds by the reiterated choice of good or evil which gradually determines character.
\end{abstract}

Romola, George Eliot

I

\section{INTRODUCTION}

Columbia Law School's ethics course, "The Profession of Law" ("POL"), is an interactive, experiential exploration of lawyer ethics. The course, required for all third-year students, is taught on an intensive basis during the first week of the fall semester. It begins on Monday morning, the first day of the semester, and runs through mid-afternoon on the following Friday. The course has five goals: to introduce students to the rules that govern professional conduct; to help them develop an analytic framework for making ethical decisions in those broad areas where the rules do not give clear answers; to provoke them to think about what it means to be an ethical practitioner; to help them explore the relationship between their personal morality and professional ethics; and to give them the opportunity to practice ethical decisionmaking.

At Columbia, as at many other law schools, previous efforts to design an ethics course had been less than successful. The POL designers worked under the hypothesis that most ethics courses failed to engage students because the issues did not seem real or relevant. To address these deficiencies, the course draws on the methodology of clinical legal education. It puts students in a role and asks them to deal, in role, with issues that most of them are likely to encounter, regardless of their future areas of practice. Students are asked to reflect on what their role-playing performance has taught them about the interplay between ethical rules and their own visions of what it means to be a good lawyer.

Copyright $(9) 1996$ by Law \& Contemporary Problems

* Clinical Professor of Law, Columbia University.

1. POL was created with support from the W.M. Keck Foundation and was designed by my colleagues Jim Liebman and Harriet Rabb, who passed on to me the opportunity to administer the course. This essay draws heavily on material prepared by them, and benefits from comments by Jim Liebman, Lance Liebman, and David Wilkins. 
The course uses three simulations. In the first, the Devon Leasing simulation, ${ }^{2}$ which is based loosely on the OPM case, ${ }^{3}$ students are placed in the role of a junior partner in a law firm that must decide whether the ethical rules require it to withdraw from further representation of its major client. In the John Henry Quiñones simulation, ${ }^{4}$ the students play the role of a public defender representing Quiñones in his upcoming trial for felony murder and later, after conviction and a death sentence, when he wants to drop his appeal. The course concludes with the Travis simulation, ${ }^{5}$ in which students working in small groups negotiate a separation agreement on behalf of either Millie or Carter Travis.

POL is a resource-intensive, administratively complex enterprise. In its most recent incarnation, eight faculty members taught the Devon problem and an additional six taught the Quiñones simulation. The Travis divorce negotiation requires even more staffing: thirty-two teachers, most of whom are practicing lawyers who volunteer their time; five walkie-talkie equipped high school and college students who help manage logistics; a faculty coordinator; and two support staff. 6

One of the most interesting and successful aspects of POL is the involvement of practicing lawyers in both the design and teaching phases. A distinguished group of graduates served as advisers to and worked with the faculty members who designed the course. ${ }^{7}$ The Travis simulation teachers have included senior litigators from major New York law firms, legal-aid lawyers, prosecutors from the U.S. Attorney's office, in-house counsel for corporations, and lawyers only a few years out of law school. These practitioners make the ethical issues raised seem both real and relevant to the students by connecting them to the practitioners' real life experiences. The practitioners who have taught the Travis simulation are so enthusiastic that some have altered vacation plans in order to participate, and we have a steady stream of volunteers who have heard about the program and want to take part.

In order to ensure that students get the same basic core experience regardless of who their teachers are, we have developed extensive teaching notes that focus both on content and pedagogy. We also have faculty meetings

2. The Devon simulation was written by Harriet Rabb, a George M. Jaffin Professor of Law and Social Responsibility at Columbia Law School, who is currently on leave and serving as General Counsel for the Department of Health and Human Services.

3. The case study “OPM Leasing Services, Inc." (in which OPM stands for Other People's Money) is a case in which the founders of OPM used the company to defraud lenders. The founders were convicted of fraud and given prison sentences. See PhILIP HEYMAnN \& LANCE LiEBMAN, THE SOCIAL RESPONSIBILITY OF LAWYERS: OPM LEASING SERVICES, INC. 184-215 (1988).

4. The Quiñones simulation was written by Jim Liebman, Professor of Law, Columbia University.

5. The Travis simulation was written by Harriet Rabb, Professor of Law, Columbia University.

6. While Columbia has chosen to operate POL on an intensive basis, the materials would also work in a traditional course, although, perhaps, with somewhat lessened impact.

7. The following served as members of the Advisory Board: Molly S. Boast, Jane E. Booth, Juan Cartagena, Hon. Marvin E. Frankel, Ronald Gilson, Harvey J. Goldschmid, Paul R. Grand, Robert M. Heller, Jeh C. Johnson, Philip A. Lacovara, Nathan Leventhal, George W. Madison, Elizabeth Jane Oestreich, Benito Romano, Minna Schrag, Hillard Wiese, and Fredric W. Yerman. 
before and, usually, after each simulation to discuss format and teaching goals, to evaluate the sessions, and to get suggestions for the following year.

The following sections of this essay will describe the course in some detail, summarize student reaction, discuss some of the lessons the faculty has learned from offering the course, and, finally, explore the future challenges presented by POL and teaching ethics generally.

II

DESCRIPTION OF THE Profession OF LAW COURSE

\section{A. The Initial Assignment}

A few weeks before the end of spring semester, second-year students receive a memorandum that introduces them to POL and gives them reading and writing assignments to complete during the summer. First, the students read material introducing them to competing views of both the lawyer's professional role and the basic aims of professional ethics rules. ${ }^{8}$ They then read through the Model Rules ${ }^{9}$ and the Code. ${ }^{10}$ After completing the reading assignment, students are asked to choose provisionally among a range of competing philosophical views regarding the basic role lawyers ought to assume in carrying out their professional ethical obligations. In some cases, those competing models define the lawyer's role in terms of the lawyer's overriding professional goal. For example, the overriding professional goal could be to maximize the client's autonomy, to act morally, to serve as moral conscience for the client, or to guarantee the justness of the outcomes the client achieves. In other cases, the competing models define the lawyer's role in terms of the kind of interactions the lawyer typically should attempt to have with the client. The lawyer could listen, advise when and as requested, facilitate, caution and counsel, even when not requested, or challenge the client and advocate the attorney's view of the most just outcome.

Having decided provisionally which view fits their own conception of lawyer ethics, students are asked to write a short paper explaining the reasons for that choice and how it would lead them to respond in one of several hypothetical or real situations presenting difficult ethical questions. The papers are handed in at the beginning of the first class.

8. During the first two years of POL, we used a selection of articles that we compiled. We are currently assigning selections from Deborah L. Rhode, PROFESSIONAL RESPONSIBILITY: ETHICS BY THE PERVASIVE METHOD (1994). Asking students to pick from a selection of models of ethical lawyering seems a useful way to introduce them to the literature, even at the risk of initially suggesting an oversimplified either-or choice. As the course unfolds, the students have the opportunity to see that life (even simulated life) is more complex than the models and that their choices may be greatly influenced by context.

9. Model Rules of Professional Conduct (1992).

10. MODEl CODE OF PROFESSIONAL RESPONSIBILITY (1990). 


\section{B. The Introductory Class}

The course begins with an opening session taught to the entire class of 350 , which is designed to emphasize the relevance of the week's work to their professional lives and to explore the summer readings and the positions students took in their initial papers. Assembling the entire third-year class as a single group in an academic setting adds a certain amount of ceremony to the course opening. The size of the group no doubt also means that participation in the discussion is limited.

Though brief, the opening session sets the philosophical stage for the more concrete discussions that follow in the next sessions. The faculty member who leads this opening discussion is charged with broadly reviewing the models of lawyer roles presented in the summer readings. The themes of the summer readings and initial class provide a frame of reference throughout the week.

\section{The Devon Leasing Simulation}

The introductory class is followed by the Devon Leasing simulation, which changes the level of focus from the philosophical "forest" of the summer readings, initial paper, and first class, to the doctrinal trees. It does so by presenting students with an unfolding story of fast-paced events in the midst of which certain ethical decision points are "freeze-framed." Students are called upon to interact with particular characters, and the relatively clear rules applicable to those decisions are discussed.

This session is designed to introduce students to ethical problems encountered in private firm and business-oriented practice (for example, conflicts between individual and corporate clients, demands of confidentiality versus nonparticipation in or disclosure of ongoing frauds and crimes, and circumstances in which withdrawal as counsel is permitted or required). The students face the pressures created by competing economic and ethical demands and consider the first of several contexts in which to test the various models of professional ethical behavior that they provisionally chose in the first session.

The Devon problem is taught to groups of ninety students by four teams of faculty members. The faculty teams consist of one expert on corporate law and one teacher with a background in experiential learning. ${ }^{11}$

Several pedagogical techniques are used to keep students engaged in the exercise during a long day that begins at 9 a.m. with the introductory class and ends at 6 p.m. The professors act out seven vignettes that frame each decision point. They then freeze the action, ask all the students to decide how they would proceed, and invite volunteers to join in by acting as a junior partner.

11. During the first two years of POL, the Devon Problem was taught to the entire 350-person class in a teaching tour de force by Professors Jerry Lynch and Harriet Rabb. Beginning with the fall 1995 offering, we decided to divide the class into four sections, giving up the benefits of a uniform initial experience in favor of increased opportunity for student participation in smaller sections. 
The student role players and their classmates then have the opportunity, out of role, to defend the junior partner's chosen course of action. For example, in scene two, the student junior partners are asked by a senior partner, played by a faculty member, to attend an unscheduled meeting with Bruce Austin, CEO of Devon. Austin tells his lawyers that as an officer of Devon, he has engaged in certain acts of financial impropriety which he greatly regrets. Austin assures his lawyers that the bad behavior has ended and offers to tell them the details if they promise not to tell anyone what he is about to confess. Before he can say more, the senior partner asks Austin why he is moved to make this confession. Austin says his conscience is bothering him, and he wants to get the matter off his chest. At this point, the senior partner asks the "junior partners" to step into a conference room without the client.

The senior partner-teacher begins the discussion by asking the junior partners what should be done at this point. Should they press Austin for details? Encourage him to remain silent? What are the counseling issues? How do they reconcile the lawyer's obligation to be fully informed with Austin's attempt to put conditions on the lawyer's attempt to acquire information? How do they explain the lawyer's confidentiality responsibilities and limitations on confidentiality? Who is the client? As students develop ideas of how to respond to Austin, they are asked to role-play their proposed responses with the teacher acting the part of Austin.

As the other scenes unfold in the course of the simulation, students, still in role as a junior partner in the firm, have further conversations with Austin, the chief financial officer, and other lawyers, all played by one of the teachers. At the end of each scene, we supplement the discussions with a set of written questions designed to make the students commit to a position about how the law firm should respond to the ethical problem featured in each scene. The students then compare their decisions to those of their classmates before moving on to the next set of events. The use of freeze-frame demonstrations followed by the mandatory decisionmaking is designed to convey various aspects of "reallife" ethical decisionmaking: the way situations with ethical consequences evolve and shift as new information becomes available; a sense of the speed with which complicating events may occur; the lawyer's frequent inability to avoid ethically charged decisions; and the financial, interpersonal, and other pressures that compete with ethical considerations.

In making their decisions throughout the Devon simulation, students are asked to attend not only to the ethical rules but also to their own and the firm's economic and status goals. The students thus are placed in a position to "lose" not only if they make incorrect decisions according to a generally applicable set of ethical rules but also if, out of an excess of ethical caution, they make decisions that are economically or professionally damaging to themselves, to the firm, or to the client. 
At the end of the four-and-one-half hour Devon simulation, ${ }^{12}$ the law firm decides it must withdraw as counsel. The students are then presented with a final problem: how to respond to a phone call from a close friend asking whether there is anything the friend's law firm should know before taking on the Devon Corporation as a client.

The students are given one hour to write a letter to the friend, and are charged with trying to reconcile several goals: discharging the personal and moral obligation not to sandbag the friend and his firm; giving the friend as much warning as the rules permit regarding the representation; and preserving the confidences and secrets that are more apt to be disclosed in oral communication. At the end of the hour, students return to class, hand in their letters, and compare their letters to one written by a Columbia professor who is an expert on corporate law.

\section{The John Henry Quiñones Simulation}

On the second day, the class is divided into six sections of approximately sixty students to work on the Quiñones simulation. This simulation uses an intermediate focus that invites students to consider how their broader philosophical views on the lawyer's role affect their responses to ethical problems that are not clearly or satisfactorily addressed in the ethics rules.

Students are asked to take on the role of a staff attorney in the Office of the Public Defender in Columbia, Georgia. They are assigned to represent John Henry Quiñones, who is charged as an accessory to a capital felony murder, an offense for which he may be sentenced to death if convicted. In the morning session, each class watches a videotape of an interview between Quiñones and his lawyer. In the initial segment of the videotape, Quiñones demands that he be allowed to testify and makes statements that might be interpreted as revealing a plan to testify falsely. Subsequent segments of the videotape provide a focus for discussion by demonstrating three different ways a lawyer might approach conversations with the client. The segments explore possible legal and factual positions and ways to prepare the client to testify without aiding client perjury in the process. This segment of the Quiñones problem explores the tension between, on the one hand, the lawyer's need to earn the client's trust and also to trust the client and, on the other hand, the lawyer's need to uphold the integrity of the judicial system. The problem also raises questions about issues that might arise in the lawyer-client relationship because of differences in ethnic or class background.

In the afternoon, students continue their representation of Quiñones in a new context. Having been convicted of felony murder and sentenced to death, Quiñones has unexpectedly directed his lawyer to drop his appeal a few days before the appeal brief is due. During the class, students examine the role of lawyer as counselor as they wrestle with various questions: To what extent must

12. The day is broken up by a welcome-back picnic lunch for the third-year class. 
a lawyer help a client pursue an objective that is lawful but politically, morally, or religiously repugnant to the lawyer? When may a lawyer pursue an objective the lawyer believes to be in the best interest of the client but which is contrary to the objectives that the client asks the lawyer to pursue? How far must and may a lawyer's counseling of a client extend in regard to political, moral, religious, psychological, and interpersonal ramifications of the lawful objectives chosen by the client? Again the discussion is aided by videotapes prepared for the course. The tapes show the lawyer's initial discussion with Quiñones about his decision to withdraw his appeal, followed by three possible ways the lawyer might continue that discussion. The lawyer's capacity to change her ethical obligations by changing her assessment of the client's competence provides a parallel to the morning session's exploration of the lawyer's ability to change her ethical obligations by changing her degree of certainty about whether or not the client is preparing to commit perjury.

\section{E. The Travis Simulation}

The Travis divorce simulation is the emotional and experiential high point of the course. As the students take on representation of either Millie or Carter Travis, we want them to blend references to the Code and the Rules with their own sense of themselves as good lawyers. The problem is designed to help them explore where, given their own values and vision of lawyering, they will draw the line regarding what they may and will do to advance their client's interests. ${ }^{13}$

On Wednesday, Thursday, and Friday, the class is divided into thirty-two law firms of eleven or twelve students. Half the class is assigned to represent Millie Travis and the other half to represent Carter Travis as they negotiate a separation agreement. A teacher works with each firm throughout the simulation and plays the role of the client for the opposing firm. Most of the thirty-two teachers are Columbia Law School graduates ${ }^{14}$ who volunteer twoand one-half days to teach the simulation and who also spend significant amounts of time preparing for the simulation, including time spent at faculty meetings prior to and during the simulation. Materials guide the faculty through each stage of the simulation, and detailed teaching notes explain the goals of each segment, the roles of the teachers (observer, facilitator, didactic discussion leader) during each segment, the issues that are likely to arise, and the tasks that should be accomplished. The teaching notes also provide questions that can be used to guide students through each segment of the simulation. Other teaching aids include a summary of facts and a list of the ethical issues raised in each client's initial interview.

13. With the instructions for the Travis simulation, students receive a financial fact sheet prepared by the parties and a Reference Service Abstract of Matrimonial Law.

14. A few are practitioners with close ties to Columbia or members of the Columbia Law School faculty or administration. 
The simulation begins with each half of the class viewing a videotape of an initial interview with its client. The interview is laden with ethical issues. The students then spend the rest of the day working individually and then in their respective law firms identifying the ethical issues, planning how to deal with those issues both in meetings with their clients and in the negotiation with the other side, planning how to identify and pursue the client's goals in the upcoming client interviews and negotiation sessions, and meeting with their clients.

During the second day of the simulation, students draw cards assigning their roles as, for example, client interviewer or negotiator. Then the students conduct follow-up interviews with their clients, counsel their clients about the ethical issues, and negotiate a settlement agreement with the opposing law firm.

Once the negotiations begin, the firms are split into two negotiating subteams made up of three negotiators and three observers. At various times during the simulation, the negotiators and observers switch roles. One teacher observes each negotiation. After the simulation ends, the teachers meet for three hours with the faculty directors of POL to discuss the events of the day and prepare for the next morning's debriefing classes.

Some of the most powerful teaching during POL takes place on the final Friday. In a succession of meetings with their clients, adversaries, and teachers, students must face the consequences of their behavior during the simulation. During the first of three debriefing sessions, each firm meets with the faculty member who played its client. In this session, students are asked to consider the impact of their ethical decisions on their clients. The session begins in role with two students from each negotiating sub-team presenting their team agreement to the client. The client-teacher responds initially in role and then out of role. Teachers are encouraged to raise several issues: the student lawyers' failure to counsel them about the implications of client proposals (implications that become apparent to the client once the agreement has been made); the student lawyers' failure to follow client instructions (for example, by making an issue out of the items of personal property that the clients already agreed on); or student lawyers' behavior during counseling sessions that left the client uncertain about whether to recommend the firm in the future.

Each firm then meets with its teacher/facilitator to discuss the extent to which the firm followed its plan for dealing with ethical issues, the reasons for any deviations, and the extent to which efforts to identify and approach ethical problems lead to sound or unsound ethical judgments when action finally was required. They consider the ways the pressures of the moment and the thrill of the negotiating game interfered with following through on plans for dealing with ethical issues. Despite working together during the planning stage of the simulation, the two six-person negotiation sub-teams often perform in very different ways during the negotiation. The students are encouraged to consider the factors that produced different results. Students also consider the impact of their ethical decisionmaking on their own sense of themselves as professionals. 
Following the first two debriefing sessions, each side sees the other side's initial interview videotape. Opposing firms then meet to discuss the ethical choices made by each firm during the negotiations. In these sessions, which are sometimes heated, students have the opportunity to learn how their opponents rate their ethical behavior. Teachers are encouraged to make the point that, even if the students are satisfied with their own behavior, the fact that other lawyers think ill of them can have important consequences for their reputations and their business dealings.

\section{F. Final Events}

POL ends with all of the students collectively revisiting the themes of the first class and discussing the impact of their experiences during the week on their initial views of lawyer roles and ethics. ${ }^{15}$ The final assignment is a paper, due two weeks after the end of the course, on one of the issues in the Quiñones simulation. In the papers, the students discuss how they would handle the issue and explore how that decision was affected by their role choice in the original paper and by their experiences during the week.

\section{G. Evaluation of Student Performance}

Because much of the learning that goes on during POL depends on student participation, students are required to attend each session of the course and attendance is taken in each session. Students who do miss part of POL are given make-up assignments that involve watching a videotape of the missed class and reacting in writing to what they watched.

Students are graded on a credit/no-credit basis. In addition to attendance, four components are considered in the grading process: the initial role paper; the Devon letter; their performance during the Travis simulation; and the final Quiñones paper. The papers are read by one of ten faculty members, several of whom do not teach during POL. All of the failing and marginal papers (approximately fifteen to twenty each year) are also read by the two faculty members who administer the course. In this way, we are able to ensure that a uniform standard is used to identify students who should not receive credit for the course. The size of the Devon and Quiñones classes makes it impossible to evaluate class performance in those sessions, but student work on the Travis simulation is taken into account. Teachers are asked to take note of students whose performance was outstanding and of those who failed to participate

15. Even though it theoretically makes sense to end the week with a return to the broader philosophical issues with which we began, it has been difficult to keep students engaged during the final class. We are considering either redesigning this session or abandoning it. If we do not have a final "big theme" session, we will need to redesign the students' final paper to achieve some of the goals of that class. On the other hand, simply hearing a few classmates declare to the others present that their view of their proper legal role has changed or been refined on the basis of actually living out that role in the simulations provides an important message that should be preserved. 
appropriately. That information can tip students whose written work is marginal into either the credit or no-credit group.

Because students must successfully complete POL in order to graduate, those whose work is not of credit quality receive a letter asking them to meet with one of the two faculty directors of POL. In most cases, the students are given the choice of rewriting one or more of the papers or of taking on a new writing assignment in order to bring their work up to a credit-worthy standard. In the first year of the course, approximately twenty-five students' work was not worthy of credit. Last year, that number fell to approximately twelve.

\section{III}

\section{STUDENT RESPONSE}

The strong positive impact of POL on students is evidenced by their responses to the course evaluation, their individual comments about the course, their final papers, follow-up focus group lunches, and individual conversations with students. All of that data reveals that the course successfully involves the students with the material and helps most of them begin to develop an analytical framework for making decisions about the ethical issues they will face in practice.

On evaluation forms filled out during the final POL class, students not surprisingly gave the Travis simulation the highest rating. On a five-point scale, it received an overall rating of $4.54 .^{16}$ The Devon simulation received an overall rating of 3.08 and the Quiñones problem a 3.74. It is not surprising that the small-section, highly interactive Travis simulation received such a high rating. In fact, we have some sense that the ratings for Quiñones and Devon might have been higher had those experiences not been in competition with the Travis simulation. When asked to compare POL to other courses they have taken at Columbia Law School, students gave POL a 3.70 rating, meaning they consider it to be an above-average course. This latter data may be compared to course evaluations of Columbia Law School's two preceding mandatory ethics courses, each of which consistently rated well below average.

We were particularly pleased with the high marks the POL teachers received. Ratings for our graduates and other practitioners who taught the Travis simulation were especially high. Students were impressed with the way these teachers explained and presented the course material, connected the course to their own experiences in practice, and showed respect and concern for the students. The overall average for outside teachers of the Travis Simulation was 4.29. The average rating for the Quiñones teachers was 4.05 and for the larger section Devon teachers 3.82.

16. Except where otherwise noted, evaluation ratings in this section are the average for the three years of the course. The overall effectiveness ratings for the Quiñones and Travis problems are the averages of only the first two years' responses (1993-94) because that question was not included in the most recent course evaluation. 
Students did have some negative things to say about POL in comments on the evaluation forms. They found the first two days too long given the relatively passive format of the Devon and Quiñones simulations compared to the Travis simulation. They disliked having to buy books that are used for only one week. Finally, one persistent complaint targets our decision to focus on ethical decisionmaking instead of the law of lawyering. Each year some students have been dissatisfied because POL does not teach the rules in more detail, that is, in a way aimed at preparing them for the Multistate Professional Responsibiity Exam. Nevertheless, students rated the Devon simulation's effectiveness at 3.30 for providing them with an overview of ethical rules.

Since POL was designed to overcome the failure of earlier courses to make ethical issues seem real and relevant to our students, we were especially pleased with student responses to questions about the effectiveness of the simulations at engaging them in role-play. The Quiñones problem received a rating of 3.54 and the Travis 4.54 , while, predictably, Devon was only rated at 2.59. In assessing how effective the simulation was at making them "feel the pressures involved when a lawyer must respond to the ethical rules while trying to further his/her personal, economic, and professional goals and the goals of his/her client and firm," students rated Devon 3.01, Quiñones 3.44, and Travis 4.42. The Travis problem was rated 4.43 on its effectiveness at helping students consider what they will and will not do for their clients.

\section{IV}

\section{CONCLUSION}

A. What the Faculty has Learned From the First Three Years of POL

The professors who devised POL have learned a great deal from three years of teaching the simulations to more than 1,000 Columbia students.

First, with carefully designed teaching materials, law school graduates and members of the faculty who are not experts in professional responsibility can be drawn on to mount a complex, sophisticated, and well-received ethics course. In the three years that POL has been offered, the Dean, sixteen faculty members, the Dean of Students, the Assistant Dean for Public Interest, and a librarian have taught one or more segments of POL. Approximately sixty alumni have taught the Travis simulation. Almost all have been willing to sign up for return engagements.

Second, when students are asked to deal with ethical issues in role, they become engaged with the material and can see its relevance to their professional lives.

Third, the use of initial and post-course papers was a successful device for establishing the philosophical framework for the course and for requiring students to reflect on the week's experiences. The quality of the initial papers (from thoughtful to barely adequate) and the variety of views reflected in the students' role choices were about what we had expected, but we were surprised 
by the number of students who stated in those first papers that the only ethical decision they would make in the first five years of practice was where to work. They began the course with the inaccurate, pessimistic, perhaps even irresponsible view that in their early years as professionals, once they make the decision to work in a large firm, they will simply be expected to do what they are told, not to participate as decisionmakers on issues presenting ethical difficulties. Their responses to the questions on the course evaluation about the success of the course at engaging them and making them aware of the competing pressures that they will experience during practice indicates that they left the course with a more nuanced view of their responsibility to attend to ethical decisionmaking. In the final papers, a gratifying number of students (my estimate is about 15 to 20 percent) mentioned changing or modifying their initial role choice because of their experiences in the course.

Fourth, POL powerfully demonstrates the importance of good counseling skills both to ethical practice and to good outcomes for the client. During the Travis simulation, student lawyers were likely to have trouble resolving ethical dilemmas in ways that satisfied their professional responsibilities and achieved their client's needs if they did not know how to sit down with a client and raise tough questions, if they backed off in the face of client resistance, if, when faced with client ambivalence or inconsistent direction, they picked the goals that were most comfortable or most familiar to the lawyer and pursued only those, if they were uncomfortable with anger or other emotions that clients bring to their lawyers' offices, or if they imposed their own values and their own senses of what the best outcome would be on the clients, rather than listening and following the client's directions.

Fifth, even though the students were generally sophisticated in their analysis of ethical issues, their analysis was often trumped by the power of the game-the drive to win-once they began negotiations. During the Travis divorce negotiation, too many students lost sight of their ethical obligations and their clients' interests as they got caught up in a competitive, adversarial negotiation. The students were terrific at recognizing the issues but not as terrific when it was time to play the game-to counsel the client and to conduct the negotiation. Often, the desire to win at the negotiating table overrode both ethical and prudential concerns. Often, the student lawyers withheld information and reached an agreement that was unlikely to last and that, when it unraveled in the future, would leave the clients in a worse position-financially and emotionally - than they would have been in if represented by a problemsolving attorney. In a small but disturbing number of situations, student lawyers lied. Even so, the chance to be exposed to their own conduct, and to have it criticized by student associates, student adversaries, respected lawyers, and faculty members makes us slightly more sanguine about those students' prospects.

Sixth, it can be hard, even in an ethics course, to resist group pressure and to hold on to one's view of the ethical way to proceed. After the course, some 
students reported they had tried during the Travis simulation to raise ethical issues, to put on the ethical brake, but that they gave in to group pressure when their efforts were dismissed by their more vocal partners. The power of the herd is not a new insight, but it is useful to be reminded of its strength and to see how, even in a course focusing on ethics, attempts to discuss an issue can be defeated if vocal members of the group are uninterested in or uncomfortable talking about the issue.

\section{B. Future Challenges}

POL has all the virtues and all the vices of an intensive one-week course. Students are focused on the subject because they are not diverted by other courses or by the myriad extra-curricular activities that take over their lives later in the semester. On the other hand, the pace of the course does not allow time for reflection and does not permit deeper exploration of the many important major and minor issues that arise as the week proceeds. The breadth of course coverage is also limited, leaving students without even an introductory exposure to many critical and basic ethical issues.

Thus, POL is only one step toward appropriate consideration of professionalism issues by our law students. So far, the faculty concerned with this subject believe it is a better step than the available alternatives. We doubt that the "pure pervasive" method will reach as many students as POL, ${ }^{17}$ and we have not seen mandatory full-semester courses that hold student attention and achieve the involvement from "regular" faculty that POL continues to have. ${ }^{18}$ We therefore plan to continue with POL. This framework gives important time to the subject of professionalism (the first week of third year, immediately after a summer job and law-firm interview week), thus allowing the school to declare that the subject is important in a way that occasional references in regular classes or a traditionally taught two-hour course does not. However, we are well aware that five days of instruction, even with simulations that engage many students, is not a sufficient program, and that our failure to have follow-up offerings must be remedied.

As Columbia considers its next steps, we face the challenge of not having found a permanent member of the faculty who specializes in this important subject. The area remains high on the list of subject-matter areas for faculty recruitment. But, as indicated by the number of faculty members who have been willing to take on POL teaching assignments, the Columbia faculty is relatively strong in professors who are seriously interested in this field and have useful professional experience. It has been possible to mount the POL course

17. While Columbia has never formally surveyed its faculty to determine the extent to which attention to ethical matters pervades the curriculum, my impression is that ethical matters are addressed in a large number of courses.

18. In the fall of 1995 , the full-time faculty spent 125.5 hours teaching POL ( 70 hours on Devon Leasing and Quiñones and 59.5 hours on Travis), which is more than four times the number of faculty teaching hours in a traditional one-semester, two-credit ethics course. 
drawing heavily on regular professors and full-time lawyers. The same talent pool could staff a course that followed and built upon POL. Some of this building occurs in the treatment of ethics in other courses. In an ideal world, we would follow POL with a menu of courses, most of which would use the simulation, joint faculty, and practitioner model to explore ethical issues likely to arise in specific practice areas, along with a traditional law of lawyering course. Such courses would provide greater opportunity for reflection, breadth of coverage, and depth of study, as well as additional opportunities for in-role practice of ethical decisionmaking.

As a result of our experiences in POL, Columbia is beginning to expand its curriculum of simulated courses to address the needs so clearly revealed. Spring 1996 is the debut semester for a new course in negotiation taught by two adjunct faculty and one member of the full-time faculty, using the POL model of collaboration in course design by faculty and practitioners. This new course gives intensive attention to the interplay of negotiation strategy, skills, and ethics that is at the center of the Travis simulation in POL.

As Columbia considers the proper curricular steps that would build on POL, we will need to answer a number of questions: How many students would enroll in a one- or two-hour optional course that followed the mandatory POL? Would regular or adjunct faculty be able to create a course that held student attention? What can we learn from other schools' experiments in teaching professional responsibility? Have other schools developed materials that provide both depth and breadth of coverage while attracting better student attention than traditional casebooks? How long can we use our current simulations before they become stale? Where will the resources come from to develop fresh problems?

Our experiences in POL leave us with a sense of satisfaction with what we have achieved thus far, but acutely aware of curricular gaps that we must fill and of challenges that must be addressed by both the academy and the bar. In particular, we need to find ways to teach students that being a forceful advocate does not always require adversarialness, that meeting a need of the other side does not have to be a loss for their clients, and that clients are usually interested in solving a problem rather than in defeating the other side. We also need to find ways to address our students' pessimism about the possibility of being an ethical practitioner, and we need to be sure that our graduates understand that good ethical practice and good client outcomes are powerfully linked to good counseling and negotiation skills. Finally, we need to continue the efforts we have begun in POL to find ways to help students understand and learn to resist the forces pushing them away from wise and ethical lawyering. 